\title{
CLIMATE, AIR POLLUTION, AND MORTALITY
}

\author{
BY
}

\author{
J. T. BOYD
}

London School of Hygiene and Tropical Medicine

Seasonal variation in disease has attracted the interest and speculation of writers since the days of Hippocrates (Greenwood, 1921). More recently Farr, in the course of his wide-ranging researches on 19th century vital statistics, published several studies relating to medical meteorology and drew attention to the excessive mortality that often occurred during periods of very low temperature (Farr, 1885). During the 20th century other workers have demonstrated the close nature of this association between temperature and mortality, and the London fog disaster of 1952 (Logan, 1953) focused attention on the effects of air pollution and the role it may play in any general relationship between climate and mortality.

The present studies were planned to make some further investigation of associations in time between mortality, particularly respiratory mortality, and different indices of meteorological conditions and atmospheric pollution. They were based on data relating to both a metropolitan environment, London Administrative County, and a rural environment in East Anglia. The East Anglia data covered all rural districts of Norfolk, Suffolk, Cambridge, and the Isle of Ely, and were included to provide a control study in which possible effects of gross urban pollution would be eliminated from associations between meteorological conditions and mortality. In both areas, the various associations were measured by a series of time correlations relating weekly mortality to temperature, absolute humidity, and visibility, while for the metropolitan area it was also possible to examine correlations between mortality and both sulphur dioxide and smoke pollution. Relevant data (Appendix) were supplied from official sources:

(a) Weekly mortality figures by age and cause from the General Registrar Office; (b) Daily meteorological readings by the Meteorological Office of the Air Ministry, Harrow;

(c) Daily pollution measurements by the Fuel Research Station (D.S.I.R.).

The choice of a time unit for the study, one week, was governed by this being the shortest period for which data on deaths were readily available. Thus weekly deaths, by cause and age, provided indices of mortality, and basic data on each of the other variables were grouped to form parallel series of weekly indices.

The indices derived from the London data were as follows:

(1) Mortality.-Weekly deaths from (a) bronchitis and pneumonia and $(b)$ heart disease.

(2) Temperature.-Weekly average of mean daily minimum temperature $\left({ }^{\circ} \mathrm{F}\right.$.) derived from recordings at ten stations in London A.C.

(3) Absolute Humidity.-Weekly average mean daily vapour pressure recordings (m.b.) at Kew.

(4) Sulphur Dioxide.-Weekly average of mean daily $\mathrm{SO}_{2}$ concentrations (p.p.m.) derived from recordings at five stations in London A.C.

(5) Smoke Pollution.-Weekly average of mean daily smoke recordings $\left(\mathrm{mg} / \mathrm{m}^{3}\right)$ at five stations in London A.C.

(6) Fog.-Weighted average* of number of hours per week with visibility less than 440 yards, from recordings at Kingsway and Croydon.

\footnotetext{
* For each week the number of hours of visibility less than 440 yards were weighted as follows:

Number of hours of visibility less than 44 yards $\quad \ldots \quad \times 10=a$

Number of hours of visibility 44-219 yards .. $\ldots \times 2=b$

Number of hours of visibility $220-439$ yards $\quad \cdots \times 1=c$

The value $(a+b+c)$ was derived separately for Kingsway and Croydon data, and the average of these two values was taken weekly index of visibility.
} 
For the rural districts of East Anglia, comparable indices were derived, in like manner, for mortality, temperature, humidity, and fog, the basic data for the last three indices coming from recording stations in the rural area.

The period of study extended over the years 1947 to 1954 but, since any relationship between mortality and the factors under investigation seemed likely to be more evident during the winter, the analysis was restricted to the winter months of those years. Each "winter" was arbitrarily defined as the 26-week period centred in the end of one calendar year and the beginning of the next, and, using this definition, data from seven winters, 1947-48 to 1953-54 inclusive, were available for analysis.

All correlations were calculated separately for each winter and the overall pattern of association between variables was obtained by averaging correlations over the seven winters. An alternative approach would have been to average the indices for each of the 26 winter weeks and to use the composite, or averaged, data to measure correlation between the different variables. This alternative approach was however rejected since, with the known broad seasonal influences on each of the factors concerned, it would inevitably have caused an artificial smoothing of time trends for all variables and artificially high correlations between them. The method adopted, i.e. averaging correlations rather than indices over the seven winters, also seemed to make more allowance for possible changes in mortality patterns over the period, and for any factors which might have an effect in the interplay between variables in some winters but not in others. As will be noted later, the investigation itself provided some evidence of such a factor, namely influenza, which when prevalent appeared to distort some of the associations under study.

Throughout the main part of the analysis, weekly deaths were correlated with indices representing climatic and pollution factors in the same week and also with similar indices of conditions in each of the six preceding weeks.

\section{RESULTS}

Primary Correlations-London Administrative COUNTY

Temperature.-Respiratory mortality appeared to be most closely associated with temperature conditions of the 2 weeks immediately preceding death (Table I).
TABLE I

LONDON ADMINISTRATIVE COUNTY: AVERAGE CORRELATIONS BETWEEN WEEKLY DEATHS FROM BRONCHITIS AND PNEUMONIA AND RELATED TEMPERATURE INDICES

\begin{tabular}{c|c|c|c}
\hline \multirow{2}{*}{$\begin{array}{c}\text { Temperature } \\
\text { Relating to }\end{array}$} & \multicolumn{2}{|c|}{ Weekly Deaths from Bronchitis and Pneumonia } \\
\cline { 2 - 3 } & Under 1 yr & 45 yrs and Over & 65 yrs and Over \\
\hline Same Week & -0.220 & -0.499 & -0.491 \\
Week - 1 & -0.459 & -0.720 & -0.706 \\
Week - 2 & -0.404 & -0.719 & -0.710 \\
Week -3 & -0.320 & -0.668 & -0.655 \\
Week -4 & -0.322 & -0.640 & -0.625 \\
Week -5 & -0.305 & -0.628 & -0.614 \\
Week -6 & -0.330 & -0.580 & -0.570 \\
\hline
\end{tabular}

When weekly deaths from bronchitis and pneumonia, at 45 years and over, were correlated with temperature, a correlation around -0.5 was obtained with temperature index of the same week perature of the preceding week. This level was maintained using temperature 2 weeks before death and was followed by a consistent decline when deaths were related to temperature of successively earlier weeks. While consistent the decline was a gradual one and the correlation coefficient between mortality and temperature conditions 6 weeks before remained considerable. An exactly similar pattern emerged from the analysis relating to deaths at 65 years and over. At the other end of the age scale (under one year) association between deaths and temperature was less marked, the highest coefficient being under $-0 \cdot 5$. Although correlation levels were lower in this youngest age group, the same general pattern remained evident and the highest coefficient were again attained with temperature of Weeks -1 and -2 .

When correlations for individual winters were examined separately (Table II, opposite), some divergences from the general trend became apparent. Alternate winters (1947-48, 1949-50, 1951-52, 1953 1954) displayed the pattern already described, but trends in the remaining winters $(1948-49,1950-51$, 1952-53) did not show the same consistency. A common factor to each of the winters in the first group was their relatively low influenza mortality compared with winters in the second group (Table III, opposite). These data were used to separate winters according to concurrent influenza mortality and the average temperature correlations for "low" and "high" influenza winters were examined separately (Table IV, opposite).

For low influenza winters the pattern displayed was similar to, but more accentuated than, that 
TABLE II

LONDON ADMINISTRATIVE COUNTY: CORRELATIONS BETWEEN WEEKLY DEATHS FROM BRONCHITIS AND PNEUMONIA, AT 45 YRS AND OVER, AND RELATED TEMPERATURE INDICES IN THE WINTERS 1947-48 TO $1953-54$ INCLUSIVE

\begin{tabular}{|c|c|c|c|c|c|c|c|}
\hline \multirow{2}{*}{$\begin{array}{l}\text { Temperature } \\
\text { Relating to }\end{array}$} & \multicolumn{7}{|c|}{ Winters } \\
\hline & $1947-48$ & $1948-49$ & 1949-50 & $1950-51$ & 1951-52 & $1952-53$ & 1953-54 \\
\hline $\begin{array}{c}\text { Same Week } \\
\text { Week }-1 \\
\text { Week }-2 \\
\text { Week }-3 \\
\text { Week }-4 \\
\text { Week }=5 \\
\text { Week }-6\end{array}$ & $\begin{array}{l}-0.361 \\
-0.726 \\
-0.807 \\
-0.670 \\
-0.568 \\
-0.676 \\
-0.780\end{array}$ & $\begin{array}{l}-0.540 \\
-0.736 \\
-0.571 \\
-0.582 \\
-0.606 \\
-0.709 \\
-0.659\end{array}$ & $\begin{array}{l}-0.631 \\
-0.836 \\
-0.806 \\
-0.716 \\
-0.623 \\
-0.579 \\
-0.494\end{array}$ & $\begin{array}{l}-0.277 \\
-0.486 \\
-0.570 \\
-0.640 \\
-0.754 \\
-0.795 \\
-0.781\end{array}$ & $\begin{array}{l}-0.583 \\
-0.835 \\
-0.786 \\
-0.746 \\
-0.662 \\
-0.577 \\
-0.464\end{array}$ & $\begin{array}{l}-0.411 \\
-0.530 \\
-0.649 \\
-0.652 \\
-0.632 \\
-0.438 \\
-0.319\end{array}$ & $\begin{array}{l}-0.688 \\
-0.890 \\
-0.842 \\
-0.667 \\
-0.632 \\
-0.621 \\
-0.561\end{array}$ \\
\hline
\end{tabular}

TABLE III

RECORDED DEATHS FROM INFLUENZA, AT 45 YRS AND OVER, IN THE WINTERS 1947-48 TO 1953-54

\begin{tabular}{c|c|c}
\hline \multirow{3}{*}{ Winter } & \multicolumn{2}{|c}{ Number of Deaths } \\
\cline { 2 - 3 } & $\begin{array}{c}\text { London Administrative } \\
\text { County }\end{array}$ & $\begin{array}{c}\text { Rural Districts of } \\
\text { East Anglia }\end{array}$ \\
\hline $1947-48$ & 60 & 14 \\
$1948-49$ & 251 & 60 \\
$1949-50$ & 171 & 27 \\
$1950-51$ & 717 & 284 \\
$1951-52$ & 90 & 9 \\
$1952-53$ & 481 & 70 \\
$1953-54$ & 54 & 7 \\
\hline
\end{tabular}

obtained in the overall analysis. The association between mortality and temperature of 1 or 2 weeks previously, as measured by a coefficient of $-0 \cdot 8$, was closer, and there was a sharper decline in size of correlation when mortality was related to temperature of earlier weeks. In contrast, the average temperature correlations from high influenza winters did not reveal the same regular pattern. They no longer reached their maximum with temperature of the 2 weeks immediately preceding death and, while there was a gradual increase in correlation back to that with temperature 4 weeks before death, they did not display any clear cut trend comparable to that for the low influenza winters. A possible explanation of the distorting effect of influenza suggested by this broad difference is that, when prevalent, the rise and the fall of the disease may have caused sufficient fluctuation of concurrent mortality, particularly from respiratory causes, to disturb the normal relationship between temperature and mortality. In any event it is clear that this "influenza effect" has been partly responsible for the artificially high average correlations obtained in the overall analysis between mortality and temperature conditions relating to 5 or 6 weeks before death. It is probable, however, that even for low influenza winters these correlations remain elevated by a close inter-association between temperatures of successive weeks.
TABLE IV

LONDON ADMINISTRATIVE COUNTY: AVERAGE CORRE LATIONS BETWEEN WEEKLY DEATHS FROM BRONCHITIS AND PNEUMONIA, AT 45 YRS AND OVER, AND RELATED TEMPERATURE, AT 45 YRS AND OVER, AND RELATE TEMPERATURE INDICES FOR "LOW"
INFLUENZA WINTERS

\begin{tabular}{c|c|c}
\hline $\begin{array}{c}\text { Temperature } \\
\text { Relating to }\end{array}$ & “Low" Influenza & "High" Influenza \\
Winters & -0.567 & -0.409 \\
\hline Same Week & -0.822 & -0.584 \\
Week -1 & -0.810 & -0.597 \\
Week -2 & -0.700 & -0.625 \\
Week -3 & -0.621 & -0.664 \\
Week -4 & -0.613 & -0.647 \\
Week -5 & -0.575 & -0.586 \\
Week -6 & & \\
\hline
\end{tabular}

In addition to correlation based on deaths from bronchitis and pneumonia, parallel series were calculated correlating temperature with weekly mortality from bronchitis and heart disease respectively (Table V). For both mortality groupings, the pattern of correlations was essentially similar to that presented by deaths from bronchitis and pneumonia. Their time trend was, however, a little sharper than for the bronchitis and pneumonia correlations averaged over the seven winters. This was more noticeable in the correlations based on cardiac deaths and may have been due to the trends of mortality from heart disease being less affected by the presence or absence of influenza.

\section{TABLE V}

LONDON ADMINISTRATIVE COUNTY: AVERAGE CORRELATIONS BETWEEN WEEKLY DEATHS FROM BRONCHITIS AND HEART DISEASE, AT 45 YRS AND OVER, AND RELATED TEMPERATURE INDICES

\begin{tabular}{c|c|c}
\hline \multirow{2}{*}{$\begin{array}{c}\text { Temperature } \\
\text { Relating to }\end{array}$} & \multicolumn{2}{|c}{ Weekly Deaths at 45 yrs and Over } \\
\cline { 2 - 3 } & Bronchitis & Heart Disease \\
\hline Same Week & -0.538 & -0.552 \\
Week -1 & -0.727 & -0.744 \\
Week -2 & -0.694 & -0.688 \\
Week -3 & -0.638 & -0.553 \\
Week -4 & -0.620 & -0.559 \\
Week -5 & -0.604 & -0.544 \\
Week -6 & -0.559 & -0.519 \\
\hline
\end{tabular}


The separate analysis of heart disease data for high and low influenza winters (Table VI) provided some evidence supporting this explanation in that even in winters with the higher prevalence of influenza peak correlations were still attained with temperatures of the two weeks immediately preceding death.

TABLE VI

LONDON ADMINISTRATIVE COUNTY: AVERAGE CORRELATIONS BETWEEN WEEKLY DEATHS FROM HEART DISEASE, AT 45 YRS AND OVER, AND RELATED TEMPERATURE INDICES FOR "LOW" AND "HIGH" INFLUENZA WINTERS

\begin{tabular}{c|c|c}
\hline $\begin{array}{c}\text { Temperature } \\
\text { Relating to }\end{array}$ & $\begin{array}{c}\text { “Low” Influenza } \\
\text { Winters }\end{array}$ & $\begin{array}{c}\text { “High” Influenza } \\
\text { Winters }\end{array}$ \\
\hline Same Week & -0.611 & -0.473 \\
Week -1 & -0.798 & -0.672 \\
Week -2 & -0.708 & -0.661 \\
Week -3 & -0.549 & -0.559 \\
Week -4 & -0.508 & -0.627 \\
Week -5 & -0.481 & -0.627 \\
Week -6 & -0.478 & -0.574 \\
\hline
\end{tabular}

Humidity.-Correlations between weekly mortality and absolute humidity (Table VII) were so closely similar to the temperature associations that it is unnecessary to present any further detailed description of trends displayed. For all practical purposes, both as regards pattern of correlations and levels attained, the humidity correlations mirrored those of temperature. They rose to a peak coefficient of -0.7 with indices relating to conditions of the 2 weeks preceding death, the association was less strong for deaths under one year, and there was little variation between the different mortality groups examined. Separate analysis of winters with high and low influenza mortalities again demonstrated the difference between them and suggested that, as for temperature, the humidity correlation pattern was disturbed during periods when influenza was prevalent. This distorting effect was again more marked on correlations based on respiratory mortality.

TABLE VII

LONDON ADMINISTRATIVE COUNTY: AVERAGE CORRELATIONS BETWEEN WEEKLY DEATHS FROM BRONCHITIS AND PNEUMONIA AND RELATED HUMIDITY INDICES

\begin{tabular}{c|c|c|c}
\hline $\begin{array}{c}\text { Humidity } \\
\text { Relating to }\end{array}$ & \multicolumn{2}{|c}{ Weekly Deaths from Bronchitis and Pneumonia } \\
\cline { 2 - 4 } & Under 1 yr & 45 yrs and Over & 65 yrs and Over \\
\hline Same Week & -0.213 & -0.508 & -0.485 \\
Week -1 & -0.451 & -0.722 & -0.705 \\
Week - 2 & -0.404 & -0.727 & -0.718 \\
Week -3 & -0.329 & -0.674 & -0.665 \\
Week -4 & -0.332 & -0.633 & -0.617 \\
Week -5 & -0.299 & -0.636 & -0.621 \\
Week -6 & -0.341 & -0.583 & -0.573 \\
\hline
\end{tabular}

Sulphur Dioxide.-The average sulphur dioxide correlations were smaller and presented a less definite pattern than the temperature or humidity series. In general, the coefficient obtained was of the order of +0.5 and varied little when weekly mortality from bronchitis and pneumonia was correlated with sulphur dioxide concentrations of different preceding weeks (Table VIII).

TABLE VIII

LONDON ADMINISTRATIVE COUNTY: AVERAGE CORRELATIONS BETWEEN WEEKLY DEATHS FROM BRONCHITIS POLLUTION INDICES

\begin{tabular}{|c|c|c|c|}
\hline \multirow{2}{*}{$\begin{array}{l}\mathrm{SO}_{2} \text { Pollution } \\
\text { Relating to }\end{array}$} & \multicolumn{3}{|c|}{ Weekly Deaths from Bronchitis and Pneumonia } \\
\hline & Under $1 \mathrm{yr}$ & 45 yrs and Over & $65 \mathrm{yrs}$ and Over \\
\hline $\begin{array}{c}\text { Same Week } \\
\text { Week - } \\
\text { Week }-2 \\
\text { Week }-3 \\
\text { Week }-4 \\
\text { Week }-5 \\
\text { Week -6 }\end{array}$ & $\begin{array}{l}+0.297 \\
+0.382 \\
+0.351 \\
+0.342 \\
+0.345 \\
+0.372 \\
+0.309\end{array}$ & $\begin{array}{r}+0.465 \\
+0.498 \\
+0.469 \\
+0.473 \\
+0.559 \\
+0.531 \\
+0.511\end{array}$ & $\begin{array}{r}+0.444 \\
+0.501 \\
+0.464 \\
+0.454 \\
+0.546 \\
+0.521 \\
+0.496\end{array}$ \\
\hline
\end{tabular}

Thus, while the highest correlation was achieved with indices relating to 4 weeks before death, the peak in time was ill-defined, and this lack of any real time trend among sulphur dioxide correlations contrasted strongly with the regular pattern of the temperature and humidity series. There was no material difference between correlations relating to mortality at 45 years and over and those relating to deaths at older ages, and, while associations with mortality under one year again appeared to be weaker than for the older age groups, this difference was less marked than in the temperature and humidity series. Separate analyses relating sulphur dioxide pollution to bronchitis mortality and mortality from heart disease yielded results differing little from those based on deaths from bronchitis and pneumonia (Table IX).

\section{TABLE IX}

LONDON ADMINISTRATIVE COUNTY: AVERAGE CORRELATIONS BETWEEN WEEKLY DEATHS FROM BRONCHITIS AND HEART DISEASE, AT 45 YRS AND OVER, AND RELATED SULPHUR DIOXIDE POLLUTION INDICES

\begin{tabular}{c|c|c}
\hline \multirow{2}{*}{$\begin{array}{c}\mathrm{SO}_{2} \text { Pollution } \\
\text { Relating to }\end{array}$} & \multicolumn{2}{|c}{ Weekly Deaths at 45 yrs and Over } \\
\cline { 2 - 3 } & Bronchitis & Heart Disease \\
\hline Same Week & +0.481 & +0.435 \\
Week -1 & +0.474 & +0.441 \\
Week -2 & +0.451 & +0.442 \\
Week -3 & +0.451 & +0.378 \\
Week -4 & +0.548 & +0.490 \\
Week -5 & +0.512 & +0.450 \\
Week -6 & +0.499 & +0.469 \\
\hline
\end{tabular}

Correlation with deaths from heart disease was, however, slightly lower than with respiratory mortality. 
TABLE X

LONDON ADMINISTRATIVE COUNTY: CORRELATIONS BETWEEN WEEKLY DEATHS FROM BRONCHITIS AND PNEUMONIA, AT 45 YRS AND OVER, AND RELATED SULPHUR DIOXIDE POLLUTION INDICES FOR WINTERS 1947-48 TO 1953-54 INCLUSIVE

\begin{tabular}{|c|c|c|c|c|c|c|c|}
\hline \multirow{2}{*}{$\begin{array}{c}\mathrm{SO}_{2} \\
\text { Pollution } \\
\text { Relating to }\end{array}$} & \multicolumn{7}{|c|}{ Winters } \\
\hline & $1947-48$ & $1948-49$ & $1949-50$ & $1950-51$ & $1951-52$ & $1952-53$ & $1953-54$ \\
\hline $\begin{array}{l}\text { Same Week } \\
\text { Week - } 1 \\
\text { Week - } \\
\text { Week -3 } \\
\text { Week -4 } \\
\text { Week - } \\
\text { Week -6 }\end{array}$ & $\begin{array}{l}+0.530 \\
+0.666 \\
+0.426 \\
+0.426 \\
+0.717 \\
+0.785 \\
+0.693\end{array}$ & $\begin{array}{l}+0.307 \\
+0.430 \\
+0.440 \\
+0.412 \\
+0.582 \\
+0.582 \\
+0.486\end{array}$ & $\begin{array}{l}+0.618 \\
+0.675 \\
+0.640 \\
+0.562 \\
+0.468 \\
+0.399 \\
+0.278\end{array}$ & $\begin{array}{l}+0.440 \\
+0.386 \\
+0.456 \\
+0.546 \\
+0.610 \\
+0.612 \\
+0.691\end{array}$ & $\begin{array}{l}+0.348 \\
+0.443 \\
+0.605 \\
+0.659 \\
+0.578 \\
+0.535 \\
+0.478\end{array}$ & $\begin{array}{l}+0.578 \\
+0.580 \\
+0.362 \\
+0.264 \\
+0.378 \\
+0.305 \\
+0.335\end{array}$ & $\begin{array}{l}+0.431 \\
+0.303 \\
+0.354 \\
+0.445 \\
+0.579 \\
+0.496 \\
+0.616\end{array}$ \\
\hline
\end{tabular}

Examination of sulphur dioxide correlations in separate winters revealed some high individual values but failed to demonstrate any consistent pattern (Table X). The trends showed considerable variation from year to year and the suggestion in the overall analysis of a minor peak at Week -4 was not consistently present in individual winters. Nor did it appear that influenza exerted any strong effect on the pattern of association, since average correlations for low and high influenza winters (Table XI) were similar to one another and to those obtained in the overall analysis.

TABLE XI

LONDON ADMINISTRATIVE COUNTY: AVERAGE CORRELATIONS BETWEEN WEEKLY DEATHS FROM BRONCHITIS AND PNEUMONIA, AT 45 YRS AND OVER, AND RELATED SULPHUR DIOXIDE POLLUTION INDICES FOR "LOW" AND "HIGH" INFLUENZA WINTERS

\begin{tabular}{c|c|c}
\hline $\begin{array}{c}\text { SO } \\
\text { Relating to }\end{array}$ & $\begin{array}{c}\text { “Low" Influenza } \\
\text { Winters }\end{array}$ & $\begin{array}{c}\text { "High" Influenza } \\
\text { Winters }\end{array}$ \\
\hline Same Week & +0.482 & +0.442 \\
Week -1 & +0.522 & +0.465 \\
Week -2 & +0.506 & +0.419 \\
Week -3 & +0.523 & +0.407 \\
Week -4 & +0.586 & +0.523 \\
Week -5 & +0.554 & +0.500 \\
Week -6 & +0.516 & +0.504 \\
\hline
\end{tabular}

Smoke Pollution.-None of the average smoke correlations (Table XII) exceeded a value of $+0 \cdot 4$. They resembled sulphur dioxide correlations in that apart from a more definite increase between correlations relating to the same and immediately preceding weeks they display no regular trend over the time scale studied. No major differences were apparent between series for different age and mortality groupings.

TABLE XII

LONDON ADMINISTRATIVE COUNTY: AVERAGE CORRELATIONS BETWEEN WEEKLY DEATHS FROM BRONCHITIS AND PNEUMONIA AND RELATED SMOKE POLLUTION INDICES

\begin{tabular}{|c|c|c|c|}
\hline \multirow{2}{*}{$\begin{array}{c}\text { Smoke } \\
\text { Pollution } \\
\text { Relating to }\end{array}$} & \multicolumn{3}{|c|}{ Weekly Deaths from Bronchitis and Pneumonia } \\
\hline & Under 1 yr. & 45 yrs and Over & 65 yrs and Over \\
\hline $\begin{array}{l}\text { Same Week } \\
\text { Week - } 1 \\
\text { Week -2 } \\
\text { Week -3 } \\
\text { Week -4 } \\
\text { Week -5 } \\
\text { Week - } 6\end{array}$ & $\begin{array}{l}+0.112 \\
+0.334 \\
+0.282 \\
+0.319 \\
+0.331 \\
+0.338 \\
+0.357\end{array}$ & $\begin{array}{l}+0.196 \\
+0.358 \\
+0.352 \\
+0.347 \\
+0.391 \\
+0.385 \\
+0.386\end{array}$ & $\begin{array}{l}+0.186 \\
+0.348 \\
+0.355 \\
+0.341 \\
+0.394 \\
+0.381 \\
+0.377\end{array}$ \\
\hline
\end{tabular}

Though some of the individual winters showed trends similar to temperature correlations, other winters provided very different results and there was no evidence of a pattern common to all (Table XIII).

TABLE XIII

LONDON ADMINISTRATIVE COUNTY: CORRELATIONS BETWEEN WEEKLY DEATHS FROM BRONCHITIS AND PNEUMONIA, AT 45 YRS AND OVER, AND RELATED SMOKE POLLUTION INDICES FOR WINTERS 1947-48 TO 1953-54 INCLUSIVE

\begin{tabular}{|c|c|c|c|c|c|c|c|}
\hline \multirow{2}{*}{$\begin{array}{c}\text { Smoke } \\
\text { Pollution } \\
\text { Relating to }\end{array}$} & \multicolumn{7}{|c|}{ Winters } \\
\hline & $1947-48$ & $1948-49$ & 1949-50 & $1950-51$ & $1951-52$ & $1952-53$ & 1953-54 \\
\hline $\begin{array}{l}\text { Same Week } \\
\text { Week -1 } \\
\text { Week }-2 \\
\text { Week }-3 \\
\text { Week }-4 \\
\text { Week }-5 \\
\text { Week }-6\end{array}$ & $\begin{array}{l}+0.049 \\
+0.232 \\
+0.169 \\
+0.179 \\
+0.413 \\
+0.484 \\
+0.457\end{array}$ & $\begin{array}{r}+0.320 \\
+0.557 \\
+0.539 \\
+0.486 \\
+0.420 \\
+0.432 \\
+0.301\end{array}$ & $\begin{array}{r}+0.254 \\
+0.522 \\
+0.549 \\
+0.514 \\
+0.469 \\
+0.409 \\
+0.306\end{array}$ & $\begin{array}{l}+0.332 \\
+0.354 \\
+0.436 \\
+0.472 \\
+0.599 \\
+0.713 \\
+0.739\end{array}$ & $\begin{array}{l}+0.129 \\
+0.321 \\
+0.300 \\
+0.339 \\
+0.209 \\
+0.095 \\
+0.080\end{array}$ & $\begin{array}{r}+0.462 \\
+0.603 \\
+0.415 \\
+0.344 \\
+0.440 \\
+0.354 \\
+0.339\end{array}$ & $\begin{array}{l}-0.175 \\
-0.114 \\
+0.059 \\
+0.092 \\
+0.187 \\
+0.210 \\
+0.481\end{array}$ \\
\hline
\end{tabular}


Visibility.-The correlation studies did not reveal any strong association between weekly mortality and related fog indices. The average correlations (Table XIV) were small, both absolutely and relative to those attained between mortality and other measures of pollution and climate. None of the average fog correlations reached a level as high as $+\mathbf{0} \cdot \mathbf{2}$ and no definite time trend was noted in any of the mortality groupings examined.

\section{TABLE XIV}

LONDON ADMINISTRATIVE COUNTY: AVERAGE CORRELATIONS BETWEEN WEEKLY DEATHS FROM BRONCHITIS AND PNEUMONIA AND RELATED FOG INDICES

\begin{tabular}{c|c|c|c}
\hline \multirow{2}{*}{$\begin{array}{c}\text { Fog Relating } \\
\text { to }\end{array}$} & \multicolumn{2}{|c|}{ Weekly Deaths from Bronchitis and Pneumonia } \\
\cline { 2 - 4 } & Under 1 yr & 45 yrs and Over & 65 yrs and Over \\
\hline Same Week & +0.029 & +0.054 & +0.047 \\
Week -1 & +0.142 & +0.132 & +0.144 \\
Week - 2 & +0.188 & +0.060 & +0.083 \\
Week - 3 & +0.101 & +0.006 & +0.013 \\
Week - -4 & +0.128 & +0.104 & +0.108 \\
Week -5 & +0.151 & +0.138 & +0.133 \\
Week -6 & +0.127 & +0.151 & +0.134 \\
\hline
\end{tabular}

Correlations relating to separate winters (Table XV) were equally inconsistent and through one winter produced individual coefficients as high as +0.4 , the data from another showed consistently negative correlations between mortality and visibility. Repetition of the analysis using a second index of visibility, an unweighted instead of a weighted average of number of hours of fog (visibility $<440$ yards), again failed to demonstrate any general association between mortality and visibility. The results were equally inconsistent and largely followed the pattern, or lack of pattern, described above.

\section{Primary Correlations-Rural Districts of} EAST ANGLIA

Because of the difference in size of the two populations, the numbers of deaths occurring in the rural area were less than in London and several of the mortality groupings used in the London analysis provided very few weekly deaths. It was not therefore possible to use as wide a range of mortality groupings by cause and age and in East Anglia deaths from heart disease formed the main group providing adequate numbers. Deaths classified in this category amounted, on average over the seven winters, to about sixty per week at age 45 years and above, and this group was used as the principal mortality index for correlation studies in the rural area. Correlations with deaths from bronchitis and pneumonia were also calculated, though the numbers available, an average of eleven to twelve per week, were rather small for any adequate demonstration of relevant associations.

Temperature.-The association between temperature and weekly mortality from heart disease presented a not dissimilar pattern to that obtained from the London data and was again closest when mortality was related to the temperature of the immediately preceding weeks (Table XVI).

\section{TABLE XVI}

RURAL DISTRICTS OF EAST ANGLIA: AVERAGE CORRELATIONS BETWEEN WEEKLY DEATHS FROM BRONCHITIS PNEUMONIA AND HEART DISEASE, AT 45 YRS AND OVER, AND RELATED TEMPERATURE INDICES

\begin{tabular}{c|c|c}
\hline $\begin{array}{c}\text { Temperature } \\
\text { Relating to }\end{array}$ & \multicolumn{2}{|c}{ Weekly Deaths at 45 yrs and Over } \\
\cline { 2 - 3 } & $\begin{array}{c}\text { Bronchitis and } \\
\text { Pneumonia }\end{array}$ & Heart Disease \\
\hline Same Week & -0.530 & -0.616 \\
Week -1 & -0.634 & -0.698 \\
Week - & -0.658 & -0.635 \\
Week -3 & -0.647 & -0.616 \\
Week -4 & -0.641 & -0.619 \\
Week -5 & -0.675 & -0.614 \\
Week -6 & -0.663 & -0.631 \\
\hline
\end{tabular}

A further parallel was the gradual decrease in average correlations with temperature of successively earlier weeks. The range of variation was however somewhat less than for London. Since rural respiratory deaths were small in number, it was not surprising that their correlation with temperature did

TABLE XV

LONDON ADMINISTRATIVE COUNTY: CORRELATIONS BETWEEN WEEKLY DEATHS FROM BRONCHITIS AND PNEUMONIA, AT 45 YRS AND OVER, AND RELATED FOG INDICES FOR WINTERS 1947-48 TO 1953-54 INCLUSIVE

\begin{tabular}{|c|c|c|c|c|c|c|c|}
\hline \multirow{2}{*}{$\begin{array}{l}\text { Fog } \\
\text { Relating to }\end{array}$} & \multicolumn{7}{|c|}{ Winters } \\
\hline & $1947-48$ & 1948-49 & $1949-50$ & $1950-51$ & $1951-52$ & $1952-53$ & $1953-54$ \\
\hline $\begin{array}{l}\text { Same Week } \\
\text { Week }-1 \\
\text { Week }-2 \\
\text { Week }-3 \\
\text { Week }-4 \\
\text { Week }-5 \\
\text { Week }-6\end{array}$ & $\begin{array}{l}+0.018 \\
+0.261 \\
-0.038 \\
-0.117 \\
+0.039 \\
+0.203 \\
+0.141\end{array}$ & $\begin{array}{l}+0.150 \\
+0.099 \\
+0.048 \\
+0.071 \\
+0.055 \\
+0.078 \\
+0.092\end{array}$ & $\begin{array}{r}+0.039 \\
+0.365 \\
+0.187 \\
+0.028 \\
+0.105 \\
+0.199 \\
+0.130\end{array}$ & $\begin{array}{r}+0.128 \\
+0.032 \\
+0.034 \\
+0.044 \\
+0.092 \\
+0.319 \\
+0.478\end{array}$ & $\begin{array}{l}-0.213 \\
-0.085 \\
-0.009 \\
-0.017 \\
-0.119 \\
-0.268 \\
-0.265\end{array}$ & $\begin{array}{l}+0.436 \\
+0.422 \\
+0.150 \\
+0.139 \\
+0.437 \\
+0.313 \\
+0.261\end{array}$ & $\begin{array}{l}-0.177 \\
-0.1171 \\
+0.117 \\
+0.093 \\
+0.118 \\
+0.123 \\
+0.217\end{array}$ \\
\hline
\end{tabular}


TABLE XVII

RURAL DISTRICTS OF EAST ANGLIA: CORRELATIONS BETWEEN WEEKLY DEATHS FROM HEART DISEASE, AT 45 YRS AND OVER, AND RELATED TEMPERATURE INDICES FOR WINTERS 1947-48 TO 1953-54 INCLUSIVE

\begin{tabular}{|c|c|c|c|c|c|c|c|}
\hline \multirow{2}{*}{$\begin{array}{l}\text { Temperature } \\
\text { Relating to }\end{array}$} & \multicolumn{7}{|c|}{ Winters } \\
\hline & $1947-48$ & $1948-49$ & $1949-50$ & $1950-51$ & $1951-52$ & $1952-53$ & $1953-54$ \\
\hline $\begin{array}{l}\text { Same Week } \\
\text { Week }-1 \\
\text { Week }-2 \\
\text { Week }-3 \\
\text { Week -4 } \\
\text { Week -5 } \\
\text { Week - } 6\end{array}$ & $\begin{array}{l}-0.537 \\
-0.708 \\
-0.607 \\
-0.399 \\
-0.355 \\
-0.533 \\
-0.600\end{array}$ & $\begin{array}{l}-0.553 \\
-0.753 \\
-0.621 \\
-0.724 \\
-0.585 \\
-0.599 \\
-0.727\end{array}$ & $\begin{array}{l}-0.572 \\
-0.708 \\
-0.726 \\
-0.707 \\
-0.677 \\
-0.574 \\
-0.585\end{array}$ & $\begin{array}{l}-0.548 \\
-0.528 \\
-0.590 \\
-0.656 \\
-0.766 \\
-0.790 \\
-0.759\end{array}$ & $\begin{array}{l}-0.635 \\
-0.810 \\
-0.727 \\
-0.651 \\
-0.622 \\
-0.468 \\
-0.523\end{array}$ & $\begin{array}{l}-0.699 \\
-0.653 \\
-0.548 \\
-0.684 \\
-0.704 \\
-0.776 \\
-0.715\end{array}$ & $\begin{array}{l}-0.766 \\
-0.723 \\
-0.628 \\
-0.489 \\
-0.626 \\
-0.558 \\
-0.450\end{array}$ \\
\hline
\end{tabular}

not conform to the same regular pattern. Separate examination of the data for individual winters (Table XVII) and in relation to concurrent levels of influenza mortality suggested that the influenza effect already noted in the London area might also have been a factor in the disturbance of rural associations. During low influenza winters the average correlations between respiratory deaths and temperature (Table XVIII) reverted to a pattern which, having regard to the small number of deaths involved, was not inconsistent with other temperature series.

\section{TABLE XVIII}

RURAL DISTRICTS OF EAST ANGLIA: AVERAGE CORRELATIONS BETWEEN WEEKLY DEATHS FROM BRONCHITIS AND PNEUMONIA, AT 45 YRS AND OVER, AND RELATED TEMPERATURE INDICES FOR "LOW" AND "HIGH" INFLUENZA WINTERS

\begin{tabular}{c|c|c}
\hline $\begin{array}{c}\text { Temperature } \\
\text { Relating to }\end{array}$ & $\begin{array}{c}\text { "Low" Influenza } \\
\text { Winters }\end{array}$ & $\begin{array}{c}\text { "High" Influenza } \\
\text { Winters }\end{array}$ \\
\hline Same Week & -0.541 & -0.515 \\
Week -1 & -0.673 & -0.583 \\
Week -2 & -0.693 & -0.610 \\
Week -3 & -0.657 & -0.634 \\
Week -4 & -0.594 & -0.703 \\
Week -5 & -0.602 & -0.773 \\
Week -6 & -0.587 & -0.765 \\
\hline
\end{tabular}

Humidity.-Attention has been drawn to the close parallel between humidity and temperature correlations derived from the London data. This close relationship was also evident in the East Anglia analysis, where humidity correlations (Table XIX) broadly followed the patterns of temperature correlations with respect to coefficient values, time trends, and variations between individual winters.

Visibility.-The negative findings of the metropolitan visibility analysis were repeated in the rural correlations, which again failed to demonstrate any general association between weekly mortality and the fog index employed in the study. Correlations were small, their signs varied, and the same irregular variation was apparent between and within series for separate winters.

Thus, from both metropolitan and rural analysis, it appeared that weekly mortality was most closely associated with temperature and humidity of the immediately preceding weeks. The close agreement between the two analyses suggested that urban pollution, present in London but absent in East Anglia, did not have any marked effect on the general association between temperature or humidity, and mortality.

\section{Partial Correlations}

In order further to assess inter-relationships between the various factors under study, a limited number of partial first order correlations were calculated using the indices most closely associated with mortality in the primary analysis. These indices were those of temperature and humidity relating to the week immediately preceding death, and sulphur dioxide and smoke pollution indices 4 weeks before

TABLE XIX

RURAL DISTRICTS OF EAST ANGLIA: CORRELATIONS BETWEEN WEEKLY DEATHS FROM HEART DISEASE, AT 45 YRS AND OVER, AND RELATED HUMIDITY INDICES FOR WINTERS 1947-48 TO 1953-54 INCLUSIVE

\begin{tabular}{|c|c|c|c|c|c|c|c|}
\hline \multirow{2}{*}{$\begin{array}{l}\text { Humidity } \\
\text { Relating to }\end{array}$} & \multicolumn{7}{|c|}{ Winters } \\
\hline & $1947-48$ & $1948-49$ & $1949-50$ & $1950-51$ & $1951-52$ & $1952-53$ & $1953-54$ \\
\hline $\begin{array}{l}\text { Same Week } \\
\text { Week }-1 \\
\text { Week }-2 \\
\text { Week }-3 \\
\text { Week }-4 \\
\text { Week }-5 \\
\text { Week -6 }\end{array}$ & $\begin{array}{l}-0.534 \\
-0.712 \\
-0.590 \\
-0.372 \\
-0.416 \\
-0.626 \\
-0.676\end{array}$ & $\begin{array}{l}-0.525 \\
-0.744 \\
-0.603 \\
-0.715 \\
-0.642 \\
-0.614 \\
-0.670\end{array}$ & $\begin{array}{l}-0.555 \\
-0.726 \\
-0.724 \\
-0.693 \\
-0.695 \\
-0.644 \\
-0.628\end{array}$ & $\begin{array}{l}-0.562 \\
-0.561 \\
-0.602 \\
-0.627 \\
-0.721 \\
-0.776 \\
-0.717\end{array}$ & $\begin{array}{l}-0.580 \\
-0.801 \\
-0.723 \\
-0.649 \\
-0.630 \\
-0.535 \\
-0.599\end{array}$ & $\begin{array}{l}-0.617 \\
-0.628 \\
-0.582 \\
-0.663 \\
-0.722 \\
-0.739 \\
-0.724\end{array}$ & $\begin{array}{l}-0.712 \\
-0.680 \\
-0.635 \\
-0.490 \\
-0.594 \\
-0.589 \\
-0.538\end{array}$ \\
\hline
\end{tabular}


death. The mortality experience incorporated in this analysis was that from respiratory and heart disease at 45 years and over, and, as with the primary correlations, partial correlations were calculated for each winter and then averaged over the seven winters of the study period (Tables XX and XXI).

TABLE XX

LONDON ADMINISTRATIVE COUNTY: AVERAGE FIRST ORDER PARTIAL CORRELATIONS BETWEEN SPECIFIED FACTORS AND WEEKLY DEATHS FROM BRONCHITIS AND PNEUMONIA AT 45 YRS AND OVER

\begin{tabular}{l|c|c|c|c|c}
\hline & \multicolumn{3}{|c|}{$\begin{array}{c}\text { First Order Partial Coefficient with } \\
\text { Correlation } \\
\text { With }\end{array}$} & $\begin{array}{c}\text { Total } \\
\text { Coefficient }\end{array}$ & \multicolumn{3}{|c|}{$\begin{array}{c}\text { Tem- } \\
\text { perature }\end{array}$} & $\begin{array}{c}\text { Humi- } \\
\text { dity }\end{array}$ & $\begin{array}{c}\text { SO } \\
\text { Pollution }\end{array}$ & $\begin{array}{c}\text { Smoke } \\
\text { Pollution }\end{array}$ \\
\hline Temperature & -0.720 & - & -0.150 & -0.607 & -0.652 \\
\hline Humidity .. & -0.722 & -0.188 & - & -0.573 & -0.643 \\
\hline $\begin{array}{l}\text { SO } \\
\text { Pollution .. }\end{array}$ & +0.559 & +0.366 & +0.318 & - & +0.388 \\
\hline $\begin{array}{l}\text { Smoke } \\
\text { Pollution .. }\end{array}$ & +0.391 & +0.245 & +0.184 & +0.109 & - \\
\hline
\end{tabular}

TABLE XXI

LONDON ADMINISTRATIVE COUNTY: AVERAGE FIRST ORDER PARTIAL CORRELATIONS BETWEEN SPECIFIED FACTORS AND WEEKLY DEATHS FROM HEART DISEASE AT 45 YRS AND OVER

\begin{tabular}{l|c|c|c|c|c}
\hline & \multicolumn{3}{|c|}{$\begin{array}{c}\text { First Order Partial Coefficient with } \\
\text { Given Factors held Constant }\end{array}$} \\
$\begin{array}{c}\text { Correlation } \\
\text { With }\end{array}$ & $\begin{array}{c}\text { Total } \\
\text { Coefficient }\end{array}$ & $\begin{array}{c}\text { Tem- } \\
\text { perature }\end{array}$ & $\begin{array}{c}\text { Humi- } \\
\text { dity }\end{array}$ & $\begin{array}{c}\text { SO }_{2} \\
\text { Pollution }\end{array}$ & $\begin{array}{c}\text { Smoke } \\
\text { Pollution }\end{array}$ \\
\hline Temperature & -0.744 & - & -0.149 & -0.662 & -0.692 \\
\hline Humidity .. & -0.754 & -0.190 & - & -0.646 & -0.695 \\
\hline $\begin{array}{l}\text { SO } \\
\text { Pollution .. }\end{array}$ & +0.490 & +0.199 & +0.140 & - & +0.314 \\
\hline $\begin{array}{l}\text { Smoke } \\
\text { Pollution ... }\end{array}$ & +0.330 & +0.178 & +0.097 & +0.010 & - \\
\hline
\end{tabular}

Temperature and Humidity.-The two indices appeared to be almost completely dependent on one another. This was reflected in the very high correlation between them $(+0 \cdot 953)$ and the reduction in coefficient when either was correlated with mortality with the other held constant For both respiratory deaths and those from heart disease primary correlations of the order $-0.7(-0.8$ in the four low influenza winters) were reduced to -0.2 or less. This was true whether humidity was held constant in the correlation between mortality and temperature or vice versa and, although not shown in the Tables, it was equally evident in partial correlations based on the East Anglia data. Removal of pollution factors, sulphur dioxide or smoke, did not cause any marked fall in either temperature or humidity correlations. For respiratory mortality, primary coefficients were reduced from -0.7 to -0.6 , and the reduction in size of coefficient was even less for mortality from heart disease. The effect of separating sulphur dioxide from temperature and humidity correlations was slightly more pronounced than that of removing smoke from these correlations.

Sulphur Dioxide and Smoke.-The interdependence between these two indices, as measured by a correlation coefficient of +0.689 , was less marked than between temperature and humidity. The relevant partial correlations suggested that mortality was more closely associated with sulphur dioxide than with smoke pollution indices. Thus, for respiratory mortality, the smoke correlation was reduced to $+0 \cdot 1$ when sulphur dioxide was held constant, while the sulphur dioxide correlation when smoke was held constant yielded a coefficient of almost $+0 \cdot 4$. The same difference was evident from partial correlations based on deaths from heart disease. For both mortality groupings, the separation of temperature or humidity from smoke correlations reduced the latter to $+0 \cdot 2$ or less. The same reduction was apparent in sulphur dioxide correlations relating to deaths from heart disease, but those between sulphur dioxide and respiratory mortality still remained between +0.3 and +0.4 after removing temperature and humidity from the correlation.

In general, this limited partial correlation analysis confirmed the indices of temperature and humidity as those showing the closest association with mortality from respiratory and heart disease. For both factors, the respective coefficients were little reduced by partialling out either of the pollution indices. On the other hand it was clear that the nearly complete association between temperature and humidity prevented any discrimination as to their relative importance. Of the pollution indices, sulphur dioxide appeared to be the more important, in that the partial correlations with respiratory mortality, though small compared with those of temperature and humidity, remained appreciable.

\section{Relationship between Mortality and Pollution Indices at Different Temperature LeVels}

The close association between mortality and temperature was again apparent when average weekly deaths in London were analysed according to temperature of the week preceding death (Table XXII). For each of the causes of death examined, mortality increased with decreasing temperature, 
although there were differences in the relative increase for different causes. The largest occurred amongst deaths from bronchitis which, on average, increased three-fold over the range of temperature used for this analysis. Over the same temperature range deaths from pneumonia were doubled, and those from heart disease rose by about 50 per cent. While deaths in the rural districts were smaller in number, their pattern of variation with temperature was broadly similar to that shown by the London data.

TABLE XXII

AVERAGE WEEKLY DEATHS FROM CARDIO-RESPIRATORY DISEASE, AT 45 YRS AND OVER, RELATED TO TEMPERATURE INDEX OF PRECEDING WEEK

\begin{tabular}{|c|c|c|c|c|c|}
\hline \multirow[b]{2}{*}{ Area } & \multirow[b]{2}{*}{$\begin{array}{c}\text { Temperature } \\
\text { of } \\
\text { Preceding } \\
\text { Week } \\
\text { ('F.) }\end{array}$} & \multicolumn{4}{|c|}{ Average Weekly Deaths } \\
\hline & & $\begin{array}{l}\text { Bron- } \\
\text { chitis }\end{array}$ & $\begin{array}{l}\text { Pneu- } \\
\text { monia }\end{array}$ & $\begin{array}{c}\text { Heart } \\
\text { Disease }\end{array}$ & $\begin{array}{l}\text { Respira- } \\
\text { tory + } \\
\text { Heart } \\
\text { Disease }\end{array}$ \\
\hline $\begin{array}{l}\text { London Ad- } \\
\text { ministrative } \\
\text { County }\end{array}$ & $\begin{array}{c}\text { Less than } 32^{\circ} \\
32^{\circ}- \\
36^{\circ}- \\
40^{\circ} \text { and Over }\end{array}$ & $\begin{array}{r}161 \\
140 \\
93 \\
51\end{array}$ & $\begin{array}{l}62 \\
63 \\
46 \\
31\end{array}$ & $\begin{array}{l}258 \\
227 \\
198 \\
162\end{array}$ & $\begin{array}{l}481 \\
430 \\
337 \\
244\end{array}$ \\
\hline $\begin{array}{l}\text { Rural } \\
\text { Districts of } \\
\text { East Anglia }\end{array}$ & $\begin{array}{c}\text { Less than } 32^{\circ} \\
32^{\circ}- \\
36^{\circ}- \\
40^{\circ} \text { and Over }\end{array}$ & $\begin{array}{r}10 \\
8 \\
8 \\
4\end{array}$ & $\begin{array}{l}9 \\
6 \\
6 \\
2\end{array}$ & $\begin{array}{l}74 \\
65 \\
62 \\
45\end{array}$ & $\begin{array}{l}93 \\
79 \\
76 \\
51\end{array}$ \\
\hline
\end{tabular}

The visibility data available for both metropolitan and rural areas allowed an extension of this temperature analysis and an assessment of relative effects of fog in the two areas. In both, weekly mortality within temperature groupings was subdivided according to the number of hours of related fog (visibility $<440$ yards). The main feature of this analysis for the East Anglia area (Table XXIII) was the lack of any definite association between visibility and mortality under constant conditions of tem-

TABLE XXIII

RURAL DISTRICTS OF EAST ANGLIA: AVERAGE WEEKLY DEATHS FROM CARDIO-RESPIRATORY DISEASE, AT 45 YRS AND OVER, RELATED TO TEMPERATURE AND FOG INDICES OF PRECEDING WEEK

\begin{tabular}{|c|c|c|c|c|c|}
\hline \multicolumn{2}{|c|}{ Preceding Week } & \multicolumn{4}{|c|}{ Average Weekly Deaths } \\
\hline $\begin{array}{c}\text { Temperature } \\
\left({ }^{\circ} \mathbf{F} .\right)\end{array}$ & $\begin{array}{c}\text { Hours of } \\
\text { Fog }\end{array}$ & $\begin{array}{l}\text { Bron- } \\
\text { chitis }\end{array}$ & $\begin{array}{l}\text { Pneu- } \\
\text { monia }\end{array}$ & $\begin{array}{c}\text { Heart } \\
\text { Disease }\end{array}$ & $\begin{array}{c}\text { Respira- } \\
\text { tory }+ \\
\text { Heart } \\
\text { Disease }\end{array}$ \\
\hline$<32^{\circ}$ & $\begin{array}{c}0 \\
1-19 \\
20+\end{array}$ & $\begin{array}{r}8 \\
10 \\
14\end{array}$ & $\begin{array}{r}9 \\
7 \\
11\end{array}$ & $\begin{array}{l}79 \\
71 \\
74\end{array}$ & $\begin{array}{l}96 \\
88 \\
99\end{array}$ \\
\hline $32^{\circ}-$ & $\begin{array}{c}0 \\
1-19 \\
20+\end{array}$ & $\begin{array}{l}8 \\
8 \\
8\end{array}$ & $\begin{array}{l}5 \\
6 \\
6\end{array}$ & $\begin{array}{l}67 \\
64 \\
63\end{array}$ & $\begin{array}{l}80 \\
78 \\
77\end{array}$ \\
\hline $36^{\circ}-$ & $\begin{array}{c}0 \\
1-19 \\
20+\end{array}$ & $\begin{array}{l}8 \\
8 \\
7\end{array}$ & $\begin{array}{l}6 \\
6 \\
5\end{array}$ & $\begin{array}{l}59 \\
64 \\
61\end{array}$ & $\begin{array}{l}73 \\
78 \\
73\end{array}$ \\
\hline $40^{\circ}+$ & $\begin{array}{c}0 \\
1-19 \\
20+\end{array}$ & $\begin{array}{l}4 \\
4 \\
3\end{array}$ & $\begin{array}{l}3 \\
2 \\
4\end{array}$ & $\begin{array}{l}45 \\
46 \\
43\end{array}$ & $\begin{array}{l}52 \\
52 \\
50\end{array}$ \\
\hline
\end{tabular}

perature. It appeared that, within each of the different ranges of temperature, mortality levels were unaffected by variation in the number of hours of related fog. The one possible exception occurred for bronchitis mortality in weeks with a related temperature index below $32^{\circ} \mathrm{F}$. At this temperature, average deaths from bronchitis rose from eight for weeks with no preceding fog to fourteen for weeks preceded by at least 20 hours of fog.

The pattern emerging from the parallel analysis of London data contrasted sharply with that for East Anglia (Figure, overleaf) and suggested a definite association between fog and mortality when concurrent temperatures were very low (Table XXIV). When related temperature was below $32^{\circ} \mathrm{F}$. the weeks with the highest fog rating showed an average bronchitis mortality three times greater than that for weeks with the lowest fog rating. This relationship between fog and mortality was also present, though in lesser degree, for deaths from pneumonia and heart disease, the former being more than doubled and the latter increased by about one third over the same fog range. In the next temperature grouping $\left(32-35^{\circ} \mathrm{F}\right.$.), a mortality gradient remained evident for bronchitis and possibly pneumonia, but with higher temperatures (above $36^{\circ} \mathrm{F}$.), the apparent association between fog and mortality from both respiratory and heart disease had disappeared. A corollary of the mortality gradients within the lower temperature groupings was a notable accentuation of the bronchitis mortality gradient with temperature among weeks with the highest fog rating. Under these fog conditions, average weekly deaths from bronchitis increased from fifty with related temperature above $40^{\circ} \mathrm{F}$. to over 300 with temperature below $32^{\circ} \mathrm{F}$.

TABLE XXIV

LONDON ADMINISTRATIVE COUNTY: AVERAGE WEEKLY DONDON FROM CARDIO-RESPIRATORY DISEASE, AT DEATHS FROM CARDIO-RESPIRATORY DISEASE, AT
45 YRS AND OVER, RELATED TO TEMPERATURE AND FOG INDICES OF PRECEDING WEEK

\begin{tabular}{|c|c|c|c|c|c|}
\hline \multicolumn{2}{|c|}{ Preceding Week } & \multicolumn{4}{|c|}{ Average Weekly Deaths } \\
\hline $\begin{array}{c}\text { Temperature } \\
\left({ }^{\circ} \mathbf{F} .\right)\end{array}$ & $\begin{array}{c}\text { Hours of } \\
\text { Fog }\end{array}$ & $\begin{array}{l}\text { Bron- } \\
\text { chitis }\end{array}$ & $\begin{array}{l}\text { Pneu- } \\
\text { monia }\end{array}$ & $\begin{array}{c}\text { Heart } \\
\text { Disease }\end{array}$ & $\begin{array}{c}\text { Respira- } \\
\text { tory }+ \\
\text { Heart } \\
\text { Disease }\end{array}$ \\
\hline$<32^{\circ}$ & $\begin{array}{c}0 \\
1-19 \\
20+\end{array}$ & $\begin{array}{l}100 \\
102 \\
309\end{array}$ & $\begin{array}{l}40 \\
50 \\
93\end{array}$ & $\begin{array}{l}249 \\
228 \\
329\end{array}$ & $\begin{array}{l}389 \\
379 \\
730\end{array}$ \\
\hline $32^{\circ}-$ & $\begin{array}{c}0 \\
1-19 \\
20+\end{array}$ & $\begin{array}{l}106 \\
139 \\
161\end{array}$ & $\begin{array}{l}51 \\
65 \\
68\end{array}$ & $\begin{array}{l}213 \\
241 \\
218\end{array}$ & $\begin{array}{l}370 \\
445 \\
447\end{array}$ \\
\hline $36^{\circ}-$ & $\begin{array}{c}0 \\
1-19 \\
20+\end{array}$ & $\begin{array}{r}112 \\
83 \\
90\end{array}$ & $\begin{array}{l}53 \\
43 \\
45\end{array}$ & $\begin{array}{l}210 \\
191 \\
209\end{array}$ & $\begin{array}{l}375 \\
317 \\
345\end{array}$ \\
\hline $40^{\circ}+$ & $\begin{array}{c}0 \\
1-19 \\
20+\end{array}$ & $\begin{array}{l}54 \\
48 \\
50\end{array}$ & $\begin{array}{l}32 \\
28 \\
37\end{array}$ & $\begin{array}{l}166 \\
159 \\
155\end{array}$ & $\begin{array}{l}251 \\
236 \\
241\end{array}$ \\
\hline
\end{tabular}




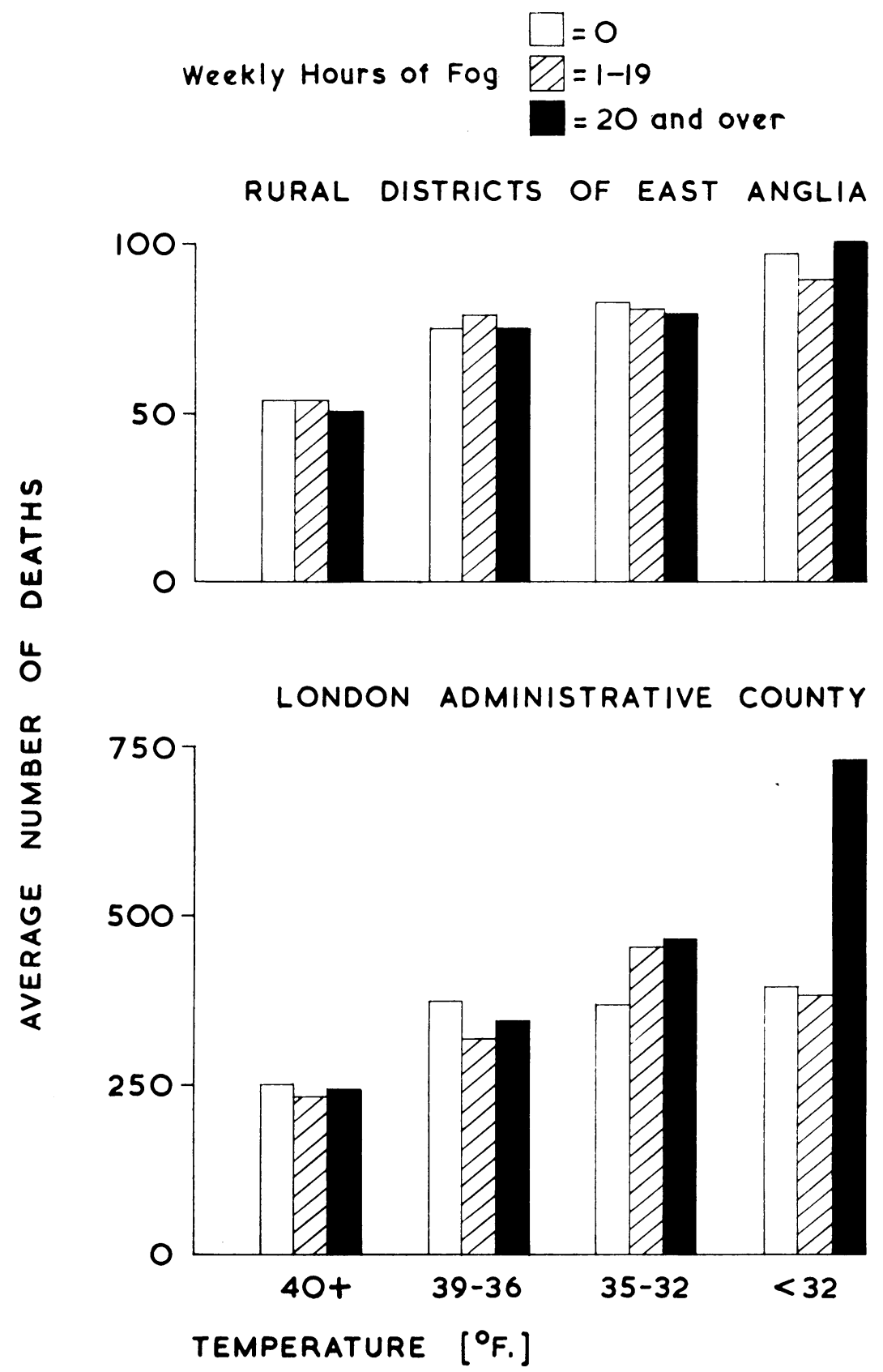

Ficiurt.--Mortality related to temperature and weekly hours of fog in London and East Anglia. 
Comparable analyses were carried out relating mortality to the other pollution indices available for the London area. Although the different arbitrary gradings prevent detailed comparisons between the three pollution indices, the general patterns emerging from the sulphur dioxide and smoke analyses were similar to that obtained from the visibility study. The data relating to all three indices suggested that the closest association between mortality and pollution was found when temperatures were very low. There were however some differences between trends displayed by the separate analyses. From the sulphur dioxide data (Table XXV), it appeared that association with mortality was largely confined to deaths from respiratory causes, and that within each temperature range average weekly deaths from heart disease varied little with differing levels of related sulphur dioxide pollution. Moreover, with respect to respiratory mortality the association, while again most marked for bronchitis and under low temperature conditions, did not as in the visibility analysis completely disappear in the upper ranges of temperature scale.

TABLE XXV

LONDON ADMINISTRATIVE COUNTY: AVERAGE WEEKLY DEATHS FROM CARDIO-RESPIRATORY DISEASE, AT 45 YRS AND OVER, RELATED TO TEMPERATURE AND SULPHUR DIOXIDE POLLUTION INDICES OF PRECEDING WEEK

\begin{tabular}{|c|c|c|c|c|c|}
\hline \multicolumn{2}{|c|}{ Preceding Week } & \multicolumn{4}{|c|}{ Average Weekly Deaths } \\
\hline $\begin{array}{c}\text { Temperature } \\
\left.\text { ( }{ }^{\circ} \mathrm{F} .\right)\end{array}$ & $\begin{array}{c}\mathrm{SO}_{2} \\
\text { Pollution } \\
\text { (p.p.m.) }\end{array}$ & $\begin{array}{l}\text { Bron- } \\
\text { chitis }\end{array}$ & $\begin{array}{l}\text { Pneu- } \\
\text { monia }\end{array}$ & $\begin{array}{c}\text { Heart } \\
\text { Disease }\end{array}$ & $\begin{array}{c}\text { Respira- } \\
\text { tory + } \\
\text { Heart } \\
\text { Disease }\end{array}$ \\
\hline$<32^{\circ}$ & $\begin{array}{c}<0 \cdot 100 \\
0 \cdot 100- \\
0 \cdot 150+\end{array}$ & $\begin{array}{r}142 \\
99 \\
236\end{array}$ & $\begin{array}{l}67 \\
45 \\
80\end{array}$ & $\begin{array}{l}281 \\
231 \\
287\end{array}$ & $\begin{array}{l}490 \\
375 \\
603\end{array}$ \\
\hline $32^{\circ}-$ & $\begin{array}{l}<0 \cdot 100 \\
0 \cdot 100- \\
0 \cdot 150+\end{array}$ & $\begin{array}{r}89 \\
134 \\
236\end{array}$ & $\begin{array}{l}45 \\
63 \\
70\end{array}$ & $\begin{array}{l}222 \\
228 \\
227\end{array}$ & $\begin{array}{l}356 \\
425 \\
533\end{array}$ \\
\hline $36^{\circ}-$ & $\begin{array}{c}<0 \cdot 100 \\
0 \cdot 100- \\
0 \cdot 150+\end{array}$ & $\begin{array}{r}81 \\
91 \\
106\end{array}$ & $\begin{array}{l}41 \\
44 \\
55\end{array}$ & $\begin{array}{l}186 \\
199 \\
207\end{array}$ & $\begin{array}{l}308 \\
334 \\
368\end{array}$ \\
\hline $40^{\circ}+$ & $\begin{array}{c}<0 \cdot 100 \\
0 \cdot 100- \\
0 \cdot 150+\end{array}$ & $\begin{array}{l}38 \\
61 \\
60\end{array}$ & $\begin{array}{l}23 \\
36 \\
38\end{array}$ & $\begin{array}{l}152 \\
170 \\
169\end{array}$ & $\begin{array}{l}213 \\
267 \\
267\end{array}$ \\
\hline
\end{tabular}

The parallel smoke analysis (Table XXVI) did not provide any new features. As with sulphur dioxide no close association with mortality from heart disease was apparent and although there was again evidence of an excess respiratory mortality with increasing pollution, this was only present in the smoke data at the lower end of the temperature scale.
TABLE XXVI

LONDON ADMINISTRATIVE COUNTY: AVERAGE WEEKLY DEATHS FROM CARDIO-RESPIRATORY DISEASE, AT 45 YRS AND OVER, RELATED TO TEMPERATURE AND SMOKE POLLUTION INDICES OF PRECEDING WEEK

\begin{tabular}{|c|c|c|c|c|c|}
\hline \multicolumn{2}{|c|}{ Preceding Week } & \multicolumn{4}{|c|}{ Average Weekly Deaths } \\
\hline $\begin{array}{c}\text { Temperature } \\
\left({ }^{\circ} \mathrm{F} .\right)\end{array}$ & $\begin{array}{l}\text { Smoke } \\
\text { Pollution } \\
\left.\text { (mg./m. }{ }^{3}\right)\end{array}$ & $\begin{array}{l}\text { Bron- } \\
\text { chitis }\end{array}$ & $\begin{array}{l}\text { Pneu- } \\
\text { monia }\end{array}$ & $\begin{array}{c}\text { Heart } \\
\text { Disease }\end{array}$ & $\begin{array}{c}\text { Respira- } \\
\text { tory + } \\
\text { Heart } \\
\text { Disease }\end{array}$ \\
\hline$<32^{\circ}$ & $\begin{array}{c}<0.250 \\
0.250- \\
0.400+\end{array}$ & $\begin{array}{r}121 \\
98 \\
217\end{array}$ & $\begin{array}{l}54 \\
54 \\
69\end{array}$ & $\begin{array}{l}265 \\
225 \\
280\end{array}$ & $\begin{array}{l}440 \\
377 \\
566\end{array}$ \\
\hline $32^{\circ}-$ & $\begin{array}{c}<0.250 \\
0.250 \\
0.400+\end{array}$ & $\begin{array}{l}145 \\
121 \\
165\end{array}$ & $\begin{array}{l}72 \\
57 \\
71\end{array}$ & $\begin{array}{l}239 \\
223 \\
228\end{array}$ & $\begin{array}{l}456 \\
401 \\
464\end{array}$ \\
\hline $36^{\circ}-$ & $\begin{array}{c}<0.250 \\
0.250 \\
0.400+\end{array}$ & $\begin{array}{r}103 \\
90 \\
85\end{array}$ & $\begin{array}{l}52 \\
44 \\
43\end{array}$ & $\begin{array}{l}209 \\
193 \\
198\end{array}$ & $\begin{array}{l}364 \\
327 \\
326\end{array}$ \\
\hline $40^{\circ}+$ & $\begin{array}{c}<0 \cdot 250 \\
0 \cdot 250 \\
0.400+\end{array}$ & $\begin{array}{l}41 \\
63 \\
48\end{array}$ & $\begin{array}{l}25 \\
36 \\
34\end{array}$ & $\begin{array}{l}155 \\
169 \\
166\end{array}$ & $\begin{array}{l}221 \\
268 \\
248\end{array}$ \\
\hline
\end{tabular}

\section{Discussion}

The associations between mortality trends and rise and fall of seasonal temperature have been analysed in several investigations based on London mortality experience and weather records. Young (1924) studied deaths from respiratory disease among children under 5 years over the period 1976-1919. Correlations with different climatic factors were, in this study, calculated separately for each of the winter weeks, i.e. for all 44 "first" weeks, for 44 "second" weeks, and seriatim for the successive 26 weeks of the arbitrarily defined winter. From the results he concluded that, of the factors examined which included rainfall and relative humidity, temperature appeared "to exercise the greatest influence on predisposing to an increased mortality from ... bronchitis". Mortality was found to be more closely related to the temperature conditions of the week preceding death than to the conditions of the same week or of 2 weeks before. Russell (1926), using longterm mortality (1870-1890) from respiratory disease at 55 years and over, and Woods (1927) working with monthly groupings of penumonia mortalities at age 40 and above for the years 1855-1904, employed similar methods to demonstrate the clear inverse relationship between number of weekly (or monthly) deaths and related temperatures. The different approach of Wright and Wright (1945) measured temperature mortality association by deriving average mortality rates from bronchitis and pneumonia and related average temperature indices for each of the 26 winters weeks over the years 1923-1929. Correlations based on these indices and relating mortality to the temperature of the same and preceding weeks 
were strikingly high and demonstrated a peak association between mortality and temperature 2 weeks (for mortality under 2 years) or 4 weeks (for mortality over 55 years) before death.

The close agreement between the general findings of these studies of mortality-temperature relationships did not however extend to their assessments of the degree of association as measured by levels of coefficient attained; e.g. where Young found an average correlation of $-0 \cdot 3$ between mortality and the temperature of the preceding week, a corresponding coefficient of almost -0.9 was demonstrated by Wright and Wright. It seems possible that such discrepancies were largely the result of differences in method, particularly in relation to the grouping of data before correlation. Thus the numerically relatively low coefficients obtained by Young may have been partly due to the distorting effect of trends in mortality from bronchitis and pneumonia over the long period studied, while the use of averaged data may have artificially elevated the correlations of Wright and Wright. The method employed in the current investigation, calculation of all correlations separately for individual winters, was adopted in an attempt to minimize such effects and also the possible distortion of association by any seasonal factor, e.g. influenza, prevalent in some winters but not in others.

The limitations inherent in all correlation studies are well recognized, and the hazards of inferring causation from association are perhaps particularly treacherous in a field where all the variables are themselves so closely linked together. Within these limitations, however, the current study has clearly indicated that, among the climatic and pollution indices examined, those relating to temperature and absolute humidity were most closely associated with mortality. Findings with respect to temperature were consistent with those already established but suggested that the association was equally evident for mortality from respiratory and heart disease, and in both rural and metropolitan environments. Highest correlations (up to -0.8 ) were achieved with indices relating to the 2 weeks immediately preceding death and correlation with conditions of successively earlier weeks declined from this peak. A similar time trend of temperature correlations relating to the weeks before death was noted by Wright and Wright. In the present study this was accentuated and there was also some internal evidence against its being rejected as an unexplained artefact in that the regular pattern of association was blurred or even lost in winters when influenza was prevalent.
In contrast to the many investigations measuring relationships with temperature, associations between seasonal variations in mortality and absolute humidity have been largely neglected. In another context, Waddy (1952), speculating on the different weather conditions associated with seasonal peaks of respiratory infection in tropical and temperate countries, put forward evidence that the common climatic factor linking these peaks was low absolute humidity. It was suggested that in temperate winters the seasonal low absolute humidity might exert a drying action on the mucosa of the upper respiratory tract and so lower its vitality and resistence to infection. The present results have found weekly mortality to be associated equally closely with absolute humidity and temperature, but the very high correlation between these two variables prevented any discrimination as to their relative importance.

Among the pollution factors examined, sulphur dioxide demonstrated the highest correlations and appeared to be more closely associated with respiratory mortality than with deaths from heart disease. Average correlations between weekly mortality and all pollution factors were, however, invariably lower than those for temperature and humidity and did not display the same regular pattern. Further, the mortality trends in relation to differing degrees of pollution within separate temperature ranges strongly suggested that the more serious effects of metropolitan fog, as measured by excessive increases in mortality, occurred only when fog was accompanied by very low temperatures. This finding is consistent with the conclusions of Russell (1924) and also allows some reconciliation between the results of the present analysis and the more dominant role of pollution suggested by shortterm studies of individual fog episodes.

I am indebted to the General Register Office for supplying the East Anglian Mortality data, and to Dr. E. T. Wilkins of the Fuel Research Station (D.S.I.R.) and Mr. R. G. Veryard of the Air Ministry Meteorological Office, Harrow, for their co-operation in allowing the use of records from these sources. My thanks are also due to Mrs. Ann Martin who did most of the abstracting of records and computing.

\section{REFERENCES}

Farr, W. (1885). "Vital Statistics", p. 411-416. Stanford, London. Greenwood, M. (1921). Proc. roy. Soc. Med. (Sect. Hist. Med.), 14, 3. Logan, W. P. D. (1953). Lancet, 1, 336.

Russell, W. T. (1924). Ibid., 2, 335. Russell, W. T. (1924). Ibid.

Waddy, B. B. (1952). Ibid., 2, 674.

Woods, H. M. (1927). J. Hyg., Camb., 26, 36

Woods, H. M. (1927). J. Hyg., Camb., 26, 36. Young, M. (1924). lbid., 23, 151 . 


\section{APPENDIX \\ Metropolitan and Rural Data on which Indices Incorporated in Correlation Studies \\ WERE BASED}

\section{London Administrative County}

(a) Mortality.-Weekly deaths by age from the following causes:

\begin{tabular}{|c|c|}
\hline Before 1950 & 1950 Onwards \\
\hline Bronchitis (21) & Bronchitis (B 32) \\
\hline Pneumonia (22) & Pneumonia (B 31) \\
\hline Influenza (9) & Influenza (B 30) \\
\hline $\begin{array}{l}\text { Coronary Disease and } \\
\text { Angina Pectoris }(19 \cdot 3)\end{array}$ & $\begin{array}{l}\text { Coronary and Arterioscle- } \\
\text { rotic Heart Disease (B 26a) }\end{array}$ \\
\hline $\begin{array}{l}\text { Myocardial Degeneration } \\
(19 \cdot 2)\end{array}$ & $\begin{array}{l}\text { Other Myocardial Degen- } \\
\text { eration (B 26c) }\end{array}$ \\
\hline
\end{tabular}

Figures in brackets after each specified cause relate to the abbreviated lists of the International Statistical Classifications of Diseases, Injuries, and Causes of Death (1938 and 1948)—as adapted and used by the Registrar General.

(b) Temperature.-Daily minimum temperature $\left({ }^{\circ} \mathrm{F}.\right)$ recorded at the following ten stations:

$$
\begin{aligned}
& \text { Kew East Ham Regents Park } \\
& \text { Wealdstone Camden Square Hampstead } \\
& \text { St. James Park Kensington Greenwich } \\
& \text { Croydon }
\end{aligned}
$$

(c) Humidity.-Daily mean vapour pressure (m.b.) recordings at Kew.

(d) Visibility.-Number of hours daily when visibility was (i) less than 44 yards, (ii) 44-219 yards, (iii) $220-440$ yards, from recordings at Kingsway and Croydon.

(e) Sulphur Dioxide.-Daily $\mathrm{SO}_{2}$ (p.p.m) readings from five recording stations:

$$
\begin{aligned}
& \text { Erith Becton County Hall } \\
& \text { Greenwich Carteret St.-Grosvenor Rd. }
\end{aligned}
$$

Carteret Street and Grosvenor Road are adjacent stations in Westminster and together provided a continuous record over the seven winters.
( $f$ ) Smoke Pollution.-Daily concentrations of smoke $\left(\mathrm{mg} . / \mathrm{m}^{3}{ }^{3}\right)$ from the same recording stations as those recording sulphur dioxide.

\section{Combined Rural Districts of Norfolk, Suffolk, CAMbridge, AND IsLe of Ely}

(a) Mortality.-Weekly deaths by age from the following causes:

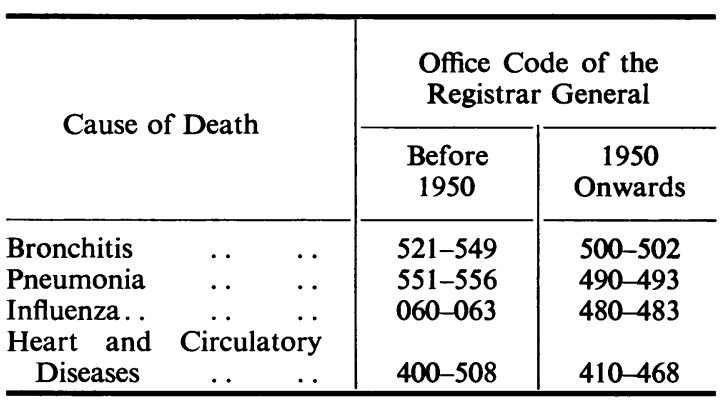

(b) Temperature.-Daily minimum temperatures $\left({ }^{\circ} \mathrm{F}\right.$.) from recording stations at Felixstowe, Mildenhall, and West Raynham.

(c) Humidity.-Daily mean vapour pressure (m.b.) recordings at Felixstowe, Mildenhall, and West Raynham.

(d) Visibility.-Number of hours daily when visibility was ( ( ) less than 44 yards, (ii) 44-219 yards, (iii) 220-440 yards, from recordings at Mildenhall and West Raynham. 